When the wave and tidal action was continued, the level of the sand against the wall fell until, after thirty-three tides, it was approximately at low-water level.

During coastal surveys in the Southwold and Christchurch areas, observations were made with drift indicators which showed that swell, accompanied by gentle or offshore winds, set up a drift which was shoreward near the bed and seaward at the surface. With steep waves accompanied by onshore winds, however, it appears that these directions are reversed. Among the new instruments developed is a miniature current meter for measuring the flow in models at velocities down to 0.25 in./sec.; this consists of a small plastic propeller the revolutions of which are timed electronically, making use of the change in conductance produced by the passage of each blade of the propeller between two electrodes.

K. F. BowDEN

\section{DRYING OF BIOLOGICAL CULTURES} UDGED by replies to a questionnaire sent out in
1948 , only twenty-five of ninety-five laboratories
in the United Kingdom then used some form of drying
technique for the maintenance of their stock cultures.
Since that time the method has been applied much
more extensively, and last September the British
Commonwealth Collections of Micro-organisms ar-
ranged a discussion of the principles and methods of
applying freeze-drying to culture maintenance to
which home and visiting scientists were asked to
contribute. The proceedings of the meeting have now
been published*. In the event the discussion centred
more on methods than on principles, about which we
seem to be woefully ignorant.

Many methods are available for drying cultures on a small scale; but the only one readily applicable to the production of a large number of ampoules are those developed by R. I. N. Greaves from his experience of drying blood products. The designer's view is that the biologist is unnecessarily exacting, and to meet his requirements apparatus has become unduly expensive. Plant has to be designed to satisfy the biologist on three major points : the temperature of drying, the speed of drying and the rate of freezing; each of these is profoundly affected by small changes in technique, such as by increasing slightly the volume of material in each ampoule. The biologists are not prepared to accept the engineer's view that further developments lie with the bacteriologist; the best possible machine for the job has not yet been produced.

Of biological factors affecting survival of microorganisms after drying, P. J. Fisher's work shows that the culture age is important, old cultures surviving better than young: it was suggested that autolytic breakdown products, such as deoxyribonucleoprotein, might have a protective action. The suspending fluid affects survival in at least two ways : during freezing, crystallization of salts may be injurious; but the main killing effect of the freezedrying process takes place when the water is first taken off under vacuum. The ultimate survival-rate

- British Commonwealth of Nations Scientiflc Liaison Offices, B.C.S.O. (London). A Discussion on the Maintenance of Cultures by Freeze-drying. Pp. ii $+48+1$ plate. (London: H.M. Stationery Office, 1954.) 5s. net. is improved by the addition of 7.5 per cent glucose to the suspending fluid, and, as survival also seems to depend on the residual moisture content of the dried product, it has been argued that glucose automatically controls the residual moisture. Unfortunately, moisture determination is technically difficult, but apparatus recently developed may so simplify the procedure that it will become part of the drying routine. With apparatus of this type it has been shown that, when solutions containing glucose are dried, moisture removal continues for three months. After sealing, there is an increase in vapour pressure in the ampoule which can be shown by a high-frequency discharge tester producing a glow inside the ampoule and not in the glass wall, and it is possible that there is a redistribution of moisture from the slow-releasing glucose to the protein which had been rapidly desiccated. In vessels closed with rubber stoppers there may be a re-hydration from diffusion of moisture through the rubber.

Freeze-drying may have some effect on the metabolism of surviving cells, and strains used for the production of antibiotics have been found to lose the ability to produce the dehydrogenase enzyme notatin. However, the experience of most of those taking part in the discussion was that, for bacteria and fungi, freeze-drying is the best method of keeping in stable form the metabolic activities which determine the biochemical reactions, antigenic patterns and the virulence of pathogens.

\section{THE FUTURE FOR TECHNOLOGICAL STUDIES}

IN his Messel Memorial Lecture to the Society of 1 Chemical Industry at Liverpool on July 14 (Chem. and Indust., 940 ; July 31, 1954), Lord Cherwell suggested that recognition by the large chemical firms in Great Britain of the fact that fundamental research is essential to progress is the main reason why the British chemical industry has been able to develop so rapidly and to overcome its handicaps. No other industry in the country has shown so much foresight and understanding of the vital importance of fundamental investigation which at first sight might seem to have no relation with practical applications. First among the industry's handicaps is the lack of facilities. in Britain for higher technological education. In spite of their efficiency and merit, the existing university departments of chemical engineering cannot meet all our requirements. In industrial atomic power the efficiency of the ehemical recovery determines whether or not the plant is an economie proposition, and many more like Sir Christopher Hinton and his team are needed to tackle such novel and difficult problems. It is not possible in Britain, said Lord Cherwell, for a young man to study at university institutions the first principles of technology and the disciplines on which it is based before deciding which particular technology to follow, and it is wrong to confine teaching of the highest branches of technology to ordinary universities. Lord Cherwell argued again for a technological university-with some three thousand students and fifty or more professorssuch as no existing university could accommodate without distorting its balance of studies.

The main obstacle to such a proposal, he urged, is intellectual snobbery regarding technology which 
still pervades Britain, although it takes just as much brains to become a first-class technologist as to become a first-class lawyer, and probably more. Since this battle which he has fought for the past twenty years has been unsuccessful, Lord Cherwell found the reason for his being awarded the Messel Memorial Medal in his early work on physical chemistry, dating from that with Prof. W. Nernst in Berlin more than forty years ago. Nernst was then mainly concerned with the heat theorem known as the third law of thermodynamics, and Lord Cherwell showed briefly how a suggestion by Einstein regarding the derivation of Planck's formula led to the discovery that action could only be transferred in units of a minute but finite size. The processes for synthesizing ammonia or petroleum depend, in fact, on the reinstatement in a space-time description of the conjugated dynamical co-ordinate.

The world is now entering an epoch of nuclear chemistry, continued Lord Cherwell, about which our knowledge is as rudimentary as that of chemistry itself a hundred and fifty years ago. No one can say whether the building up or the breaking down of nuclei will play the predominant part in generations to come. Even in classical chemistry there are problems of which we have only scratched the surface, such as the extraction of the uranium and the plutonium after irradiation from the rods full of lethal fission products and the disposal of these intensely active products. Whether we can utilize the energy potentially available has yet to be seen, and meanwhile man for the first time has it in his power to destroy all life on this planet. The question is whether he will be able to avoid some such form of universal suicide, and it is a sad reflexion on our political achievements and mental processes that, despite the universal wish for peace, man has not been able so to arrange his affairs as to avoid war and the continuing threat of war.

\section{STANDARDS AND LEVELS OF LIVING}

A COMMIT'TEE of United Nations experts has concluded that most of the short-cut methods for comparing levels of living in different countries are unsuitable and sometimes misleading. For example, both national income per capita and real wages have serious defects as indexes of levels of living*.

To present useful comparison the committee recommends a pluralistic approach by analysis of various 'components' of living which are amenable to quantitative treatment and reflect internationally accepted values or aims. The twelve components listed by the experts are: health, including demographic conditions ; food and nutrition; education, including literacy and skills; conditions of work; employment situation; aggregate consumption and savings ; transportation; housing, including household facilities; clothing; recreation and entertainment; social security; and human freedoms.

In addition, the report includes a series of more specific statistical indicators that should be used as

* Report on International Definition and Measurement of Standards and Levels of Living. (Report of a Committee of Experts convened by the Secretary-General of the United Nations, jointly with the International Labour Oftice and Unesco.) Pp. xii +96. (New York: United Nations ; Iondon: H.M. Stationery Office. 1954.) 0.80 dollars; $6 s$. ; 3 Swiss francs, a guide in measuring the various components; these indicators are chosen with the view of availability of information. In view of deficiencies of data in many countries, however, the report gives a minimum list of 'priority indicators'; it indicates how they may be obtained and adds another set of indicators to illustrate lines of further improvement.

Members of the committee recognized that an international analysis of levels of living, in terms of the components and indicators they proposed, would nevertheless fall short of giving a complete and balanced picture of the total situation. They stressed the importance of the use of descriptive materials and background information, particularly in the form of social and cultural analyses. A more direct and comprehensive assessment may be attainable by 'family living surveys' carried out by the use of sampling methods and designed to ensure international comparability.

The committee was appointed by the SecretaryGeneral of the United Nations, jointly with the International Labour Organization and the United Nations Educational, Scientific and Cultural Organization. Members came from six different countries and represented various disciplines of social sciences and statistics. They were Prof. Raymond Firth, professor of anthropology in the London School of Economics and Political Science; Prof. Philip M. Hauser, professor of sociology in the University of Chicago; Mr. Erland v. Hofsten, chief of the Statistical Section, Social Welfare Board of Sweden; Father Louis Joseph Lebret, editor of Economie et Humanisme, France; Mr. O. Alexander Moraes, acting secretary-general of the Inter-American Statistical Institute of the Organization of American States; and Mr. V. K. R. V. Rao, director of the Delhi School of Economics, University of Delhi.

\section{MANAGEMENT COSTS}

T $\mathrm{HE}$ costs of managing industrial firms have traditionally been regarded as an incidental class of expenditure. These costs have been rising rapidly and, to-day, administrative costs have become a major expense in the operation of industrial firms. By 1948, for example, of every hundred production workers in British industrial firms, twenty were administrative employees; in 1907 the number was only eight.

Information collected by Seymour Melman shows that, in Great Britain at least, there has been no correlation between increases in administrative overheads and the growth of productivity. (Manchester Guardian "Survey of Industry, Trade and Finance", 1954). In the United States, on the other hand, output per worker man-hour rose by 232 per cent from 1899 to 1947 while the administrative overhead ratio increased by over 40 per cent. In Great Britain the output per worker man-hour increased by 73 per cent from 1907 to 1948 while the ratio of administrative overheads grew by 133 per cent. It has been assumed that the growth in the cost of managing necessarily yields some economy in production; there is no evidence of any relationship of this kind.

Various reasons have been put forward to explain the growth of administrative costs in view of increasing mechanization and systematization. Melman suggests that increasing costs are due to the develop- 